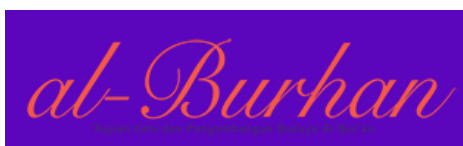

\title{
LATAR SOSIAL EKONOMI PERIODE MEKAH DALAM AL-QURAN
}

\section{The Social Economic Background of the Mecca Period in The Quran}

\section{الحلفية الاقتصادية الاجتماعية لفترة مكة في القرآن}

\section{Suhada}

STAI Al-Hikmah Jakarta Selatan, Indonesia

suhada73@yahoo.com

\begin{abstract}
Abstrak:
Latar sosial ekonomi periode Mekah dalam al-Quran memengaruhi sikap, pikiran, dan jiwa masyarakat Arab ketika itu. Fungsi harta sebagai basis tindakan horizontal diaplikasikan dengan berbagai cara dan tujuan. Artikel ini berkesimpulan bahwa harta yang berorientasi dunawi dapat menyebabkan pikiran dan jiwa masyarakat kehilangan akal dan moralnya. Sikap berlebihan terhadap harta disertai kekhawatiran kemiskinan dapat berpengaruh kepada sikap mengabaikan orang lain dan bahkan Tuhan. Al-Quran mendeskripsikan umat terdahulu yang hancur akhlaknya karena fungsi harta tidak digunakan dengan tepat. Harta dapat digunakan untuk pengelolaan ekonomi makro dalam penyelesaian krisis dan untuk kepentingan kesejahteraan masyarakat pada periode Mekkah.
\end{abstract}

Kata Kunci: Sosial, Ekonomi, Masyarakat, Mekah, Al-Quran.

\begin{abstract}
:
The socio-economic background of the Mecca period in the Qur'an influenced the attitudes, thoughts, and souls of Arab society at that time. The function of property as a basis for horizontal action is applied in various ways and purposes. This article concludes that worldlyoriented wealth can cause people's minds and souls to lose their minds and morals. Excessive attitude towards wealth accompanied by worries of poverty can affect the attitude of ignoring other people and even God. The Qur'an describes the previous people who were destroyed in their morals because the function of property was not used properly. Assets can be used for macroeconomic management in solving crises and for the benefit of community welfare in the Mecca period.
\end{abstract}

Keywords: Social, Economic, Society, Mecca, Quran.

$$
\begin{aligned}
& \text { الملنخص: } \\
& \text { أثرت الخلفية الاجتماعية والاقتصادية للفترة المكية في القرآن على مواقف وأفكار وأرواح المجتمع العربي في ذلك } \\
& \text { الوقت. يتم تطبيق وظيفة الخاصية كأساس للعمل الأفقي بطرق وأغراض مختلفة. تستنتج هذه المقالة أن الثروة } \\
& \text { الدنيوية يمكن أن تجعل عقول الناس وأرواحهم تفقد عقوهم وأخلاقهم. يمكن أن يؤثر الموقف المفرط بحاه الثروة }
\end{aligned}
$$




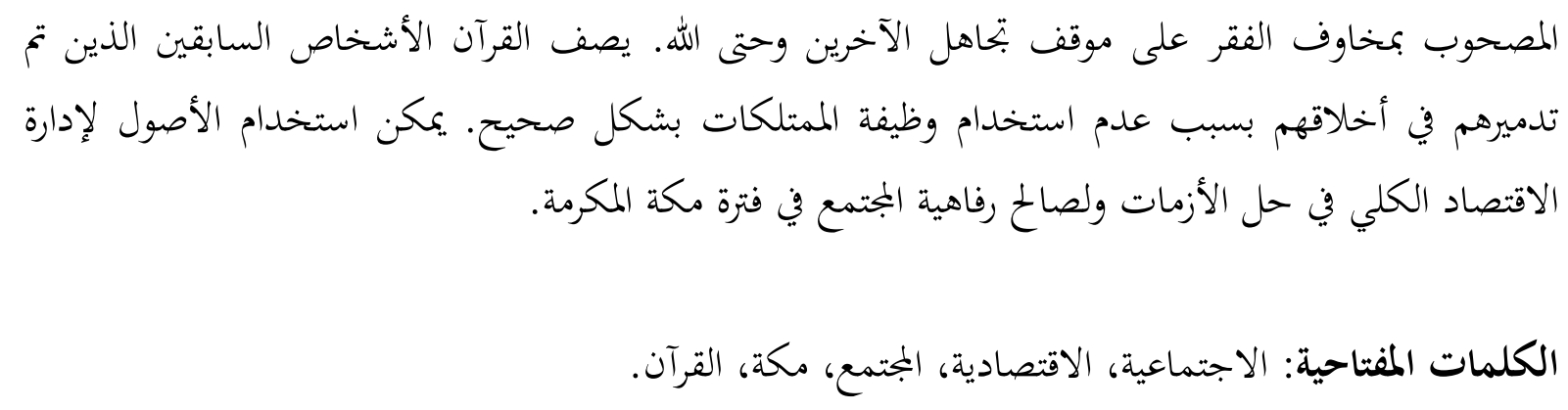

\section{Pendahuluan}

Sering orang memandang al-Quran sebagai kitab suci keagamaan yang bersifat sakral dan hanya mengandung petunjuk di bidang agama saja, seperti aspek teologi (akidah), hukum (syari'ah) dan akhlak yang tidak ada hubungannya dengan realitas kehidupan yang bersifat profan. Padahal, di dalam al-Quran selain terkandung petunjuk di bidang keagamaan dan keakhiratan, juga terkandung banyak petunjuk, ajaran dan pesan sebagai bidang keduniaan seperti politik, ekonomi, hukum, dan budaya. ${ }^{1}$

Di antara petunjuk al-Quran adalah aspek ekonomi. Ekonomi merupakan bidang kehidupan yang berkaitan dengan pemenuhan kebutuhan manusia yang baik yang bersifat fisik, material, dan jasad, secara individu maupun kelompok. Karena itu, ekonomi merupakan salah satu instrumen yang paling penting untuk mewujudkan suatu tatanan masyarakat yang dicita-citakan. Tak heran bila dalam memperkenalkan Allah sebagai dasar dan tujuan hidup, al-Qur'an sering menyebut sifat-sifatnya yang berkaitan dengan masalah ekonomi. Misalnya, dalam memperkenalkan Allah sebagai Zat yang berhak disembah, dipakai ungkapan "Tuhan pemelihara Kabah yang memberi mereka makan kelaparan” (Q.S. Quraish/106: 3); "Dia memberi makan dan tidak minta makan" (Q.S. al-An'am/6 : 14); "Dia menciptakan berbagai sumber daya (alam yang ada di bumi dan di laut sebagai sumber kehidupan” (Q.S. al-Hijr/15 : 20, alNahl/16 : 13-14); "Dijadikannya segala yang ada di muka bumi untuk dimanfaatkan bagi kebutuhan manusia” (Q.S. al-Mulk/67: 15), serta sifat-sifat Allah sebagai pemberi dan penentu rezeki manusia.

Banyaknya ayat al-Quran yang mengungkap aspek ekonomi selain menunjukkan relevansi sosiologis wahyu juga mengasumsikan adanya sistem perekonomian tertentu yang dikehendaki al-Quran. Dan hal itu sangat wajar karena pesan dan ajaran al-Quran yang komprehensif akan membawa konsekuensi adanya suatu kehidupan dan kemasyarakatan, termasuk di dalamnya aspek ekonomi. Bila dikaji secara sistematis dengan metode tafsir ditemukan beberapa fungsi perekonomian diungkap dalam al-Quran, baik yang berkaitan dengan konsumsi, produksi, maupun distribusi. ${ }^{2}$ Selain ungkapan perekonomian secara mikro, al-Quran

${ }^{1}$ Munif Mahadi Attamimi and Muhammad Hariyadi, “Al-Qur' an Answering the Challenge of

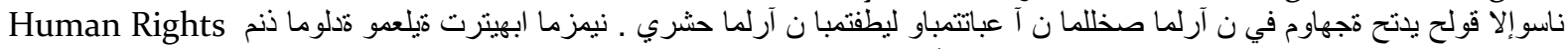

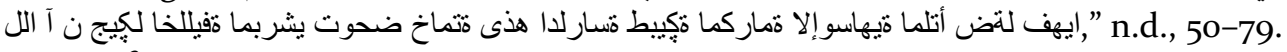

2 Muhammad Hariyadi, "METODOLOGI TAFSIR AL-QUR'AN KONTEMPORER SALAM PENDEKATAN ILMU KOMUNIKASI MODERN,” Jurnal Statement 11, no. 1 (2021): 30-40.

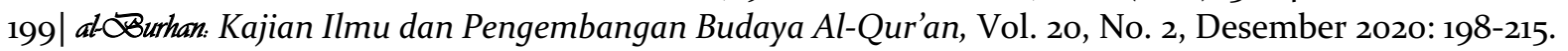




\section{Suhada}

juga mengungkap masalah perekonomian secara makro seperti tujuan ekonomi untuk mewujudkan kemakmuran yang merata harus serta bagaimana ekonomi mengatur sistem yang berlaku dalam suatu tatanan kemasyarakatan.

Sebenarnya para ulama, ilmuwan dan ekonom muslim sejak tahun 50-an hingga masa sekarang sudah banyak melakukan kajian tentang ekonomi Islam, dengan bentuk konseptualisasi dan objektifikası ilmu ekonomi Islam untuk bisa dipahami dan diimplementasikan secara teori dan praktik. Namun demikian, tulisan ini sebagai kajian awal (preliminary study) membatasi ayat-ayat al-Quran yang turun pada periode Mekah yang berbicara masalah ekonomi yang secara strategis menunjukkan pendekatan al-Quran dalam membentuk masyarakat yang mempertimbangkan konteks sosio-kultural yang melingkupinya. ${ }^{3}$

\section{Sosio-Ekonomi Arabia}

Sebelum membahas ayat-ayat ekonomi dalam al-Quran, perlu diungkap aspek sosio-ekonomi. Arabia sebagai latar belakang turunnya al-Quran, sebagaimana diketahui Hijaz, terutama Mekah, sejak abad ke-5 M dihuni dan dikuasai oleh suku Quraisy, suku keturun di Kinanah bera asal dari keturunan Arab Adnan yang semula berdomisili di Arabia yang merintis tampilnya suku Quraisy adalah Qushay ibn Kilab yang menyatukan suku Quraisy yang sebelumnya terpencar. Dia kemudian tampil sebagai pemegang kekuasaan di Mekah dalam menguasai Baitullah, Kabah, suatu tempat semua suku Arab dari berbagai penjuru.

Dengan banyaknya pendatang dari Yaman dan lain-lain yang telah memiliki peradaban, suku Quraisy dapat belajar dari mereka tentang sistem perdagangan maupun pemerintahan. Untuk itu Quraish sebagai pemimpin suku Quraisy menyusun sistem pemerintahan Mekah dan pemeliharaan Kabah maupun peziarah dengan membentuk institusi antara lain; Darun Nadwah, yaitu majelis tempat para tokoh Quraish bermusyawarah membahas berbagai urusan. Al-Liwa, komando angkatan perang yang berhak mengibarkan bendera perang dan mengambil keputusan dalam berperang. Al-Hijabah, penjagaan dan pengurusan Kabah, antara memegang kunci, membuka, dan menggantikan penutup Kabah. Siqayah al-Hajj wa Rifadatuhu, pelayanan para peziarah Kabah, baik dalam menyediakan minuman, makanan, maupun penginapan. ${ }^{4}$

Penanggung-jawab masing-masing bidang adalah kelompok anggota suku Quraisy, seperti keturunan 'Abd Manaf; Hashim, al-Mutthalib, Abdu Syams, Umayyah, Nawfal, dan keluarga keturunan 'Abd al-Dar, atau suku Asad, Tamim, Makhzum, Adi, Jahm dan Sahm. Untuk mendorong hadirnya para peziarah, masing-masing suku mempersilahkan menaruh patung di sekitar Kabah sebagai sesembahan dan tempat pengorbanan mereka, sehingga jumlah patung mencapai zoo buah lebih. ${ }^{5}$

Ramainya peziarah ke Kabah terutama pada bulan-bulan Zulqadah, Zulhijah dan Muharram dimanfaatkan pula oleh orang-orang Quraisy untuk berdagang. Pada pertengahan abad ke-6 M, saat jalur-jalur perdagangan dari timur ke Barat melalui

3 Abd. Aziz Saihu, "Implementasi Metode Pendidikan Pluralisme Dalam Mata Pelajaran Pendidikan Agama Islam Saihu," Belajea: Jurnal Pendidikan Islam 5, no. 1 (2020): 131-50, https://doi.org/10.29240/belajea.v5.

${ }^{4}$ Hassan Ibrahim Hassan, Sejarah Kebudayaan Islam (Jakarta: Kalam Mulia, 2002), 80-81.

5 'Alī 'Abd al-Rasūl, al-Mabādi al-Iqtiṣādiyah fi al-Islām, (Kuwait: Dār al-Fikr 'Arabī, 198o), 282287.

al-@urhan. Kajian Ilmu dan Pengembangan Budaya Al-Qur'an, Vol. 20, No. 2, Desember 2020: 198-215 | 200 


\section{Suhada}

laut Merah menurun, juga jalur melalui Tigris-Eufrat terganggu oleh eksploitasi Sasania dan peperangan Lakhm, Ghassan dan Romawi, Mekah menjadi bora alternatif yang penting. Para pedagang Mekah membawa rempah-rempah, sutera, obat-obatan, pakaian dan budak dari Timur atau Afrika ke Syria, dan kembali ke Mekah membawa uang, senjata, biji-bijian, dan minuman anggur.

Suku Quraisy berhasil membangun hegemoni perdagangan, kafilah-kafilahnya tersebar menguasai titik-titik perdagangan internasional, dan kota Mekah akhirnya menjadi pusat perdagangan internasional. Dalam Al-Quran dinyatakan bahwa suku Quraisy mempunyai jadwal tahunan untuk melakukan perjalanan dagang, yaitu ke selatan (Yaman) pada musim dingin (al-shita') dan ke utara (Syam) pada musim panas (al-sayf) Q.S. al-Quraisy/106 1-4), Abdullah Yusuf Ali menerangkan bahwa penguasaan suku Quraisy atas Mekah memberi tiga keuntungan; pengaruh mereka yang kuat terhadap kabilah-kabilah lain; kedudukan Mekah yang terletak di tengah-tengah Jazirah Arabia memudahkan perdagangan dan hubungan antar suku; Mekah yang oleh adat Arab tak boleh diganggu dan dirusak oleh perang dan permusuhan, membuat kedudukan mereka aman, bebas dari rasa takut akan bahaya. Kehormatan dan keuntungan mereka sebagai pemelihara tempat suci Kabah itu harus disyukuri dengan menyembah kepada Allah Yang Esa dan mengikuti ajaran yang dibawa oleh NabiNya. ${ }^{6}$

Hal ini membuat kedudukan pedagang Quraisy memperoleh kekuatan politik dengan menjalin perjanjian kerja sama (negosiasi) dengan negara-negara tetangganya, seperti Bizantium, Persia, Abisinea maupun Himyar. Di samping itu mereka juga menjalin dengan suku-suku badui yang menjadi rute perjalanan kafilah, sehingga tercipta konfederasi antar suku sebagai kekuatan yang terintegrasi.

Empat anak 'Abd Manāf, salah satu anggota suku Quraisy, menjalin hubungan dengan para penguasa-penguasa sekitarnya. Hasyim memperoleh jaminan keamanan dari penguasa Syria-Bizantium, al-Muțtalib memperoleh hal yang sama dari penguasa Yaman, 'Abd Shams memperoleh dari penguasa Abisinea, dan Nawfal memperoleh dari Kisra Persia. Jaminan sejenis juga diperoleh dari suku-suku Arab sepanjang perjalanan tersebut.

Keberadaan Mekah sebagai pusat perdagangan yang besar membuatnya sebagai pusat keuangan pula. Dalam hal ini Montgomery Watt mengatakan bahwa di Mekah terlihat berbagai aktivitas keuangan yang kompleks. Para pedagang di Mekah adalah ahli masalah keuangan, pandai dalam mengelola kredit, cakap dalam menghitung untung rugi dan berminat menanamkan investasi yang menguntungkan ke luar, mulai dari Aden sampai Gaza atau Damaskus. Jaringan finansial yang mereka bangun tidak hanya melibatkan penduduk Mekah, tetapi juga para pedagang di kawasan sekitarnya. Al-Quran turun bukan dalam lingkungan padang pasir, tetapi dalam lingkungan perdagangan yang maju. ${ }^{7}$

Hingga periode awal Islam, uang yang dipakai saat itu adalah dinar (emas) dan dirham (perak). Keduanya memiliki nilai yang tetap, dan sesuai nilai nominal uangnya (face value). Satu dinar sama dengan sepuluh dirham. Dirham sebagai satuan moneter yang berasal dari Persia lebih banyak dipakai, dibanding dinar sebagai satuan moneter

\footnotetext{
${ }^{6}$ Abdullah Yusuf Ali, Qur'an Terjemah dan Tafsirnya (Jakarta: Pustaka Firdaus, 1995), 1660.

${ }^{7}$ Asghar Ali Engineer, Asal Usul dan Perkembangan Islam, Analisis Pertumbuhan Sosio-Ekonomi (Yogyakarta : Insist dan Pustaka Pelajar, 1999), 63. 201| at-ourhan: Kajian Ilmu dan Pengembangan Budaya Al-Qur'an, Vol. 20, No. 2, Desember 2020: 198-215.
} 


\section{Suhada}

yang berasal dari Romawi, Kedua mata uang itu diimpor sesuai dengan kebutuhan sejalan dengan barang komoditas yang diekspor ke dua negara tersebut. ${ }^{8}$

Bila kaum Quraisy di Mekah hidup dan berprofesi sebagai pedagang terutama karena letak kota Makkah yang menjadi salah satu jalur lalulintas perdagangan antara Timur dan Barat, maka penduduk Madinah begitu juga Taif hidup dengan pertanian dan peternakan. Hasil pertanian utama di Madinah adalah kurma, anggur, buah ara dan gandum. Sedang peternakannya berupa sapi, onta, kambing dan kuda. Di samping itu ada juga basil kerajinan seperti tenun, pandai besi dan konstruksi bangunan. ${ }^{9}$

Yang perlu dilihat di sini bahwa perkembangan perekonomian Mekah mengakibatkan perubahan struktur sosial dengan menumpuknya kekayaan di kalangan pedagang-pedagang kaya. Transformasi sosial ekonomi pada gilirannya melahirkan benturan-benturan dalam masyarakat yang sebagian masih kuat memegang tradisi badut (kesukuan) yang konservatif. Perekonomian perdagangan yang berorientasi pasar dan bersifat individual dengan serta merta meninggalkan budaya kolektif kesukuan. Setiap orang bekerja untuk kepentingan pribadinya dan keluarga intinya. Bila dalam tradisi badui kepemilikan lebih bersifat kelompok, maka dalam masyarakat pedagang kepemilikan kolektif diabaikan dan berubah menjadi kepemilikan individu atau keluarga inti. Seorang perempuan seperti Khadijah, janda dan saudagar yang kemudian menjadi istri Nabi Muhammad, membiayai kafilahkafilah dagang sehingga memperoleh keuntungan besar dikenal mempunyai kekayaan yang sangat banyak. Seringkali terjadi seseorang bermusuhan dengan sukunya atau sesama anggota sukunya. Misalnya, terjadi perselisihan antara Abdul Mutthalib dengan pamannya Nawfal mengenai hak milik pribadi, termasuk sumur zamzam. Montgomery Watt menyatakan bahwa kecenderungan individualisme yang meninggalkan ikatan solidaritas kesukuan di Mekah adalah disebabkan oleh berkembangnya nuansa perdagangan clan kehidupan komersial. Hubungan bisnis seringkali memisahkan orang dari hubungan kesukuan. ${ }^{10}$

Proses ini pun merambah dalam aspek hukum dan politik yang secara perlahan semakin menetapkan tanggung-jawab individu lebih penting dibanding tanggungjawab kolektif kesukuan. Bila para pedagang berhasil memiliki kekayaan yang bertumpuk, di pihak lain banyak para pengrajin besi, tukang kayu, penyamak kulit, penjahit, penenun, pemeras anggur, penjaga keamanan, pelayan, penggembala maupun para budak yang hidup dalam kemiskinan dan penindasan. Kelompok ini bukan raja menghadapi kesulitan hidup tetapi juga mempunyai rasa benci kepada kelompok pedagang kaya yang tidak memedulikan nasib mereka. Tetapi, menurut HAR Gibb, terdapat potret hitam dalam kehidupan makmur di Mekah. Kondisi ini menggambarkan yang umum terjadi dalam masyarakat dagang yang makmur, di mana sebagian masyarakatnya kaya namun yang lain hidup dalam kemiskinan: para budak, kaum buruh dan mereka yang berada dalam lapisan ekonomi bawah. ${ }^{11}$

${ }^{8}$ Kadim as-Sadr, "Uang dan Kebijakan Moneter pada Periode Awal Islam" dalam Adiwarman Karim, ed, Sejarah Pemikiran Ekonomi Islam (Jakarta: IIIT, 2002), 124-126.

${ }^{9}$ Kadim as-Sadr, "Uang dan Kebijakan Moneter pada Periode Awal Islam” dalam Adiwarman Karim, ed, Sejarah Pemikiran Ekonomi Islam, 66-69.

${ }^{10}$ Muh. Zuhri, Riba dalam al-Qur'an (Jakarta: Raja Grafindo Persada), 48.

"HAR Gibb, Mohammadanism, (t.tp: London, 1919), 179. Saihu, Abd Aziz, Baeti Rohman, Suhada, "Religious Argumentation of Hate Speech (Critical Race and Racism in Hate Speech at@urhan: Kajian Ilmu dan Pengembangan Budaya Al-Qur'an, Vol. 20, No. 2, Desember 2020: 198-215| 202 


\section{Suhada}

Kondisi sosial-ekonomi yang di satu pihak mengalami kemajuan perdagangan dengan munculnya para pedagang yang makmur dan kaya sementara di pihak lain terdapat kelompok yang miskin serta terjadinya penindasan, ketidakadilan, ketidakpedulian serta kesenjangan yang mencolok antara kelompok kaya dan miskin itulah situasi yang dihadapi Nabi Muhammad sejak lahir hingga masa awal pengangkatannya sebagai Rasul. ${ }^{12}$ Menghadapi konflik karena runtuhnya moralitas kolektivisme kesukuan dan munculnya nilai-nilai materialisme dan individualisme masyarakat Mekah dalam masa transisi perekonomian itu, Asghar Ali merumuskan langkah Nabi Muhammad tampak secara revolusioner mendukung perubahan yang progresif dalam masyarakat Mekah. Dengan penuh kebijaksanaan dan untuk menghindari ketegangan, agama Baru yang dibawa Nabi Muhammad menciptakan keseimbangan antara individualisme dan kolektivisme dengan mengambil nilai-nilai suku yang tidak bertentangan dengan sejarah. Dengan ungkapan yang berbeda, Ira M. Lapidus mengatakan bahwa Al-Quran tidak menghendaki penggantian nilai-nilai luhur yang bercorak kesukuan dengan ambisi, tamak, arogansi dan hedonisme. ${ }^{13}$

Dalam melihat situasi Mekah saat itu, Ira M. Lapidus mengatakan bahwa Mekah merupakan tempat yang penuh kompleksitas dan heterogen. Masyarakatnya telah berkembang dalam batas-batas kesukuan untuk memperkuat politik dan ekonomi. Mekah merupakan masyarakat yang mengambang, warga individual terusir dari kesukuan bercampur dengan para pengungsi dan pedagang asing sehingga membuat mereka terlepas dari agama kesukuan dan konsep-konsep moral lama. Sisi positifnya, aktivitas perdagangan dengan kontaknya yang lugas melahirkan sifat individu yang bebas, kritis dan maju yang mau menerima ketuhanan dan etika universal. Sedang sisi negatifnya, masyarakat terancam oleh kompetisi ekonomi, konflik sosial, kerancuan moral dan stratifikasi sosial yang didasarkan pada nilai materi yang memudarkan nilai kolektivitas. Mekah sebagai standar politik dan ekonomi Arabia telah kehilangan moral dan sosialnya saat Arabia sedang berusaha menemukan posisinya, di Mekah diliputi oleh keruwetan dan ketidakpastian. Di tempat inilah Muhammad lahir, tumbuh berkembang, menyampaikan al-Quran dan menjadi seorang Nabi dan utusan Allah. ${ }^{14}$

\section{Ayat Ekonomi Periode Mekah}

Melihat situasi Mekah abad ke-7 M dengan corak perekonomiannya yang menonjol, maka merupakan suatu cara yang tepat bila banyak ayat al-Quran yang memakai ungkapan-ungkapan perekonomian dalam memberikan petunjuk-petunjuk moral, etika maupun hukum. Petunjuk untuk keselamatan dan kebahagiaan hidup dinyatakan dengan ungkapan "Perniagaan yang menyelamatkan dari siksa yang pedih" Q.S. al-Șaff/61 : 10); memilih kesesatan daripada petunjuk dinyatakan dengan ungkapan "Perniagaan yang rugi" Q.S. al-Baqarah/2 : 16), dan bersedekah atau berinfak

Phenomena in Indonesia)." Journal International Journal of Innovation, Creativity and Change 13.10 (2020): 1176-1194.

${ }^{12}$ Nur Arfiyah Febriani et al., "GLOBAL CITIZENSHIP EDUCATION IN THE PERSPECTIVE OF QUR ' AN AND," Psychology and Education Journal 57, no. 57 (2020): 5020-29.

${ }^{13}$ Asghar Ali Engineer, Asal Usul dan Perkembangan Islam, Analisis Pertumbuhan SosioEkonomi, 78, 8o. Lihat juga Ira M. Lapidus, Sejarah Sosial Umat Islam I \& II (Jakarta: Raja Grafindo Persada, 1999), 27.

${ }^{14}$ Ira M. Lapidus, Sejarah Sosial Umat Islam, 2728. 203| at-@Brhan: Kajian Ilmu dan Pengembangan Budaya Al-Qur'an, Vol. 20, No. 2, Desember 2020: 198-215. 


\section{Suhada}

di jalan Allah diungkapkan "Dengan memberi hutang (pinjaman) kepada Allah yang akan memperoleh pembayaran berlipat ganda" Q.S. al-Hadìd/57 : 11). Secara retorika kebahasaan, ungkapan secara metaforis (alegoris, majazi) demikian lebih mudah dipahami dan lebih mengesan bagi pendengar dan pembacanya. Secara antropologis dan sosiologis hal tersebut juga menunjukkan bahwa Al-Quran sangat sesuai dengan konteks realitas dan fenomena yang hidup dalam masyarakat yang menjadi sasarannya saat itu.

Pada tahap awal periode Mekah (611 - 623 M), ternyata sasaran utama al-Quran adalah menyadarkan manusia tentang keesaan Allah (tauhid), mengenalkan sifat-sifat Allah, penyadaran kewajiban manusia untuk beribadah kepada-Nya, mempercayai para rasul, wahyu yang diturunkan kepada mereka, mempercayai hari akhir dan perkara yang gaib. Pada saat yang sama manusia disadarkan akan adanya dasar-dasar moral, adanya yang baik dan buruk untuk mengubah akhlak mereka.

Metode pendekatan yang dipakai al-Quran untuk menanamkan akidah baru kepada masyarakat yang dipengaruhi kesenangan akan harta dan kemewahan dunia dalam situasi sekarang disebut paham materialisme itu, terlihat dengan membongkar pandangan-pandangan tentang harta dan keduniaan. Sejalan dengan itu banyak ayat Al-Quran yang turun pada saat Rasulullah berada di Mekah mengungkap tentang perekonomian, antara lain:

\section{a. Godaan Harta dan Solusinya}

Banyak ayat Makiah yang turun pada tahap awal menjelaskan tentang pengaruh harta dalam jiwa manusia. Harta, termasuk di dalamnya berbagai kekayaan, kemegahan dan kemewahan dunia memang mempunyai pengaruh yang kuat dalam jiwa manusia yang bisa menjadikannya senang bahkan bangga dan sombong. Dia akan merasa lebih tinggi dibanding mereka yang lebih sedikit hartanya apalagi yang kekurangan. Harta menjadi ukuran utama untuk menilai kemuliaan dan kebesaran manusia, tak ada lagi yang lain.

Sementara itu, mereka yang kekurangan harta, kaum fakir dan miskin, pun merasa rendah diri clan mengagungkan para pemilik harta yang kaya, tunduk kepada mereka, mengikuti segala perintah tanpa dilihat benar atau salah. Bahkan segala perilaku orang-orang kaya itu dianggap sebagai kebenaran meskipun bertentangan dengan nurani dan akal sehat. Begitulah suasana dan watak masyarakat Arab saat mula-mula diturunkan. Menghadapi hal demikian, al-Quran mengecam pengagungan harta dan para pemilik harta, seperti Q.S. al-AAlaq/96 : 67 "Ketahuilah! Sesungguhnya manusia benar-benar melampaui Batas, karena dia melihat dirinya serba cukup. Ayat yang senada dengan itu antara lain Q.S. al-Qalam/ 68 : 10-14; Q.S. al-Muddaththir/74 : 11-16; Q.S. al-Lahab/111 : 1-2; Q.S. al-Takāthur/102 : 1, 2; Q.S. al-Humazah/104 : 1-3. Yang dimaksud sebagai Orang yang tukang menyumpah, mengumpat, mencela, menyebarkan permusuhan dan menolak kebenaran adalah ibn al-Mughīrah, seorang bangsawan Quraisy yang kaya serta ahli sastra. ${ }^{15}$

${ }^{15}$ Demikian menurut Muqatil. Sementara itu Atha' dan al-Sudy berpendapat yang dimaksud adalah Akhnas ihn Syuraiq yang suka mencela bahkan mencederai Nabi. Sedang Abu Hayyan mengatakan bahwa yang dimaksud adalah semua orang yang mempunyai sifat-sifat yang disebutkan dalam surah itu, termasuk ibn al-Mughirah, Akhnas ibn Syuraiq, al-Ash ibn Wail, Umayyah ihn Khalaf dan lain-lain. Lihat Wahbah al-Zuhaylī, al-Tafsìr al-Munīr fì al-Sharī'ah wa al-Manhaj (Beirut: Dār alFikr al-Mu'așir, 1998), Juz 30, 315, 397. Aziz, Abd. "Al-Qur'an Dan Sastra: Antara Etika, Estetika, Dan atoBurhan: Kajian Ilmu dan Pengembangan Budaya Al-Qur'an, Vol. 20, No. 2, Desember 2020: 198-215 | 204 


\section{Suhada}

Dia tahu bahwa al-Quran adalah benar wahyu Allah, tetapi dia tak mau mengakuinya khawatir orang banyak akan terpengaruh. Maka dia membuat kata-kata dusta bahwa al-Quran adalah sihir dan menyebarkan bahwa Muhammad adalah pembohong. Sedang Abu Lahab yang menjadi topik utama surah al-Lahab adalah paman Rasulullah dan istrinya Ummu Jamil yang menghasut manusia dengan menyebarkan berita bohong tentang Muhammad. Selanjutnya Al-Quran mengingatkan manusia untuk bersikap rasional memandang harta, jangan mudah tertipu, karena sifat yang melekat pada manusia sendiri yang sangat mencintai harta, sebagaimana ayat Q.S. al-Ādiyāt/10o: 6-8: "Dan sesungguhnya dia (manusia) sangat bakhil karena cintanya kepada harta", atau Q.S. al-Fajr/89 : 17-20. "Sekali-kali tidak demikian), sebenarnya kamu tidak memuliakan anak yatim, memakan harta pusaka dengan cara mencampurbaurkan yang halal dan yang batil, dan mencintai harta benda dengan kecintaan yang berlebihan.

Dalam kedua surah itu kecintaan manusia yang berlebihan terhadap harta dikaitkan dengan sikap keingkaran kepada Tuhan, juga sikap mengabaikan anak yatim dan tidak mau membantu fakir-miskin, artinya, harta telah merusak jiwa dan pikiran, menggerogoti keimanan, mengabaikan rasa solidaritas dan merusak nilai-nilai akhlak mulia.

Dalam hal ini ayat-ayat Makiah yang berbicara masalah harta memberi solusi, memberi kebebasan pemikiran yang benar, memberi petunjuk kepada iman dan memperingatkan dengan berbagai watak tercela seperti zalim, kikir, egois, bohong dan terjadinya permusuhan. Hal itu dapat dilihat dari ayat-ayat Q.S. al-Alaq/ 96: 8 "Ketahuilah! Sesungguhnya manusia benar-benar melampaui batas, karena dia melihat dirinya serba cukup. Sesungguhnya hanya kepada Tuhanmulah kembali (mu)." Surah sebagai surah pertama setelah mengungkap sikap yang durhaka karena merasa kaya, diikuti dengan peringatan bahwa manusia pasti akan kembali kepada Tuhan untuk mempertanggungjawabkan segala perbuatannya, termasuk bagaimana dia mempergunakan segala kenikmatan yang diperoleh, seperti diungkap Q.S. alTakāthur. Dalam Q.S. al-Layl, Q.S. al-Fajr, Q.S. al-Ādiyāt, dan Q.S. al-Humazah, setelah mengecam sikap mencintai harta yang berlebihan langsung diikuti dengan situasi dalam kubur, ancaman siksaan neraka yang sangat mengerikan. Dalam surah al-Humazah disebut neraka Huṭamah yang membakar sampai ke jantung hati dan manusia tak akan bisa lari karena terkungkung dalam bangunan yang kokoh.

Setelah kecaman terhadap mencintai harta yang berlebihan itu, ayat-ayat Makiah yang lain memberikan pertimbangan rasional dengan membandingkan kehidupan dunia dengan akhirat. Al-Quran menunjukkan bahwa harta dan kehidupan dunia bersifat sementara dan akan rusak (fana), sementara kehidupan akherat bersifat lebih lama dan kekal sebagaimana ayat-ayat Q.S. al-A'lā/87: 16-17; Q.S. alTakāthur/102: 1-8, dan Q.S. al-Qiyāmah/75 :20-21.

Selanjutnya, kecaman terhadap harta dan keduniaan masih terus ditanamkan dalam ayat-ayat Makkiyah periode tengah dan akhir. Dalam Q.S. Yunus/10 : 24 dan Q.S. al-Kahf/18/ : 45-46, dua surah yang secara kronologis turun di tahap akhir periode Mekah, digambarkan tentang hakikat kehidupan dunia yang menarik dan

Profetika." Al-Burhan| Jurnal Kajian Ilmu dan Pengembangan Budaya Al-Qur'an 20.1 (2020): 147-163. Aziz, Abd, and M. Imam Sofyan Yahya. "Kritik Intrinsikalitas dan Ekstrinsikalitas Sastra Modern dalam Kajian Sastra Arab Modern." Mumtaz: Jurnal Studi Al-Quran dan Keislaman 3.1 (2019): 23-36.

205 | at- đurhan: Kajian Ilmu dan Pengembangan Budaya Al-Qur'an, Vol. 20, No. 2, Desember 2020: 198-215. 


\section{Suhada}

menyenangkan bagi manusia. Sementara manusia menikmatinya dan menganggap dirinya menguasai sepenuhnya keduniaan itu, namun dalam sekejap ternyata dapat sirna oleh kekuatan yang dia tak mampu mengatasinya.

Perumpamaan pencinta harta yang lebih mengena dan menyentuh diungkap dalam surah al-Qalam/18 dan al-Kahf/68. Menurut Ibn Katsir, dalam ayat-ayat tersebut bisa dilihat perumpamaan pencinta harta dan dunia seperti para pemilik kebun (ash-hab al-jannah), yang berdasar riwayat Sa'id ibn Jubair, adalah penduduk Dharwan sekitar enam mil dari San'a, Yaman. ${ }^{16}$ Bila dalam surah al-Qalam yang turun ke-2 digambarkan bagaimana para pemilik kebun yang telah berencana memetik hasil panen secara diam-diam untuk menghindari memberi sedekah kepada fakir-miskin menjadi gigit jari, kecele, karena ternyata tanaman yang akan mereka panen menjadi kering, maka dalam surah al-Kahf/18 yang secara kronologis turun ke-69 ditunjukkan perdebatan antara dua orang yang berbeda pandangannya. Orang pertama bangga karena hartanya yang banyak, menganggap dirinya lebih hebat, akan kekal dan berkuasa, sehingga menghina orang yang tidak punya sebagai lebih rendah serta mengingkari bahwa yang dimilikinya adalah berasal dari dan titipan Allah. Sementara orang kedua tak punya apa yang dibanggakan tetapi ia bertawakal kepada Allah dan berharap Allah akan memberinya yang lebih baik. Dia menasihati temannya (orang pertama) agar dia ingat bahwa dirinya dan kekayaannya berasal dari Allah dan Dia berkuasa berbuat apa pun terhadap dirinya dan kekayaannya. Tak mau mendengar nasihat temannya, akhirnya celakalah orang pertama, karena semua kekayaannya lenyap tersambar petir dan ditelan gempa, sementara tak ada seorang pun yang mampu menolongnya. ${ }^{17}$

Al-Quran juga mengungkap kisah Qarun, dalam surah al-Qashash, surah Makiah yang turun ke-49 (al-Qashash/ $28: 76-81$ ). Qarun ibn Yashhub ibn Qahits, anak paman nabi Musa, adalah salah seorang pengikut Musa yang kemudian ingkar karena disibukkan oleh harta kekayaan yang melimpah. Kesombongannya muncul dengan merasa bahwa dia memperoleh harta yang melimpah itu karena Allah tahu dirinya berhak dan karena kecintaan Allah kepada dirinya. Ia pun menentang dan menantang Nabi Musa yang memperoleh kenabian dari Allah. Dan akhirnya, dengan doa Nabi Musa, dia beserta rumah dan segala kekayaannya hilang ditelan bumi. ${ }^{18}$

Bila dalam surah-surah Makiah tahap awal turun ayat-ayat yang mengecam dan kemudian meluruskan dan memberi bimbingan tentang pandangan terhadap dunia dan harta, maka pada tahap berikutnya turun ayat-ayat yang memperingatkan caracara negatif dan curang dalam bekerja mencari harta. Namun pada periode ini al-

${ }^{16}$ Abul-Fida Isma'il Ibn Katsir, Tafsir Ibn Katsir, (Riyadh : Maktabah Riyadh alHaditsah, tt), Juz IV, 407. la menambankan menurut riwayat lain adalah penduduk Habasyah, penganut ahli kitab (Nasrani) yang mempunyai tradisi haik dalam mengolah kebun kemudian menyimpan hasilnya untuk kebutuhan setahun dan mendermakan selebihnya kepada fakir-miskin. Tetapi anak-cucu mereka menyalahkan dan mengubah tradisi itu, maka Allah mengazab mereka dengan melenyapkan tanaman mereka.

${ }^{17}$ Abdullah Yusuf Ali mengatakan bahwa peringatan orang kedua itu mengandung lima hal, yaitu : 1) menentang kesombongan orang ingkar kepada Allah, 2) berdasarkan pandangan ruhaniyahnya bahwa Allah Maha Esa Jan Maha Sempurna, 3) karunia Allah henclaknya disyukuri, 4) dia merasa cukup dengan karunia yang diberikan Allah kepadanya, 5) dia mengingatkan sifat segala isi . dunia yang sementara dan adanya hukuman Allah atas sifat kesombongan yang berlebihan. Lihat Abdullah Yusuf Ali, Qur'an Terjemahan dan Tafsirnya, (Jakarta: Pustaka Firdaus 1993), Juz I-XV, Cet. I, 740.

${ }^{18}$ Abul-Fida Isma'il Ibn Katsir, Tafsir Ibn Katsir, Juz IV, 401-402.

al@urhan: Kajian Ilmu dan Pengembangan Budaya Al-Qur'an, Vol. 20, No. 2, Desember 2020: 198-215 | 206 


\section{Suhada}

Quran belum langsung melarang kecurangan-kecurangan dalam perdagangan, tetapi mengungkap sarkasme kisah penduduk Madyan dan ashab al-aikah yang mempunyai kebiasaan curang dalam takaran dan timbangan. ${ }^{19}$ Ajakan perbaikan (dakwuh al-islah) meninggalkan kecurangan disampaikan oleh Nabi Syu'aib yang diungkap dalam surah-surah Makiah tahap pertengahan dan akhir, yaitu Q.S. al-Araf yang turun ke-39, Q.S. al-Shu'ara' ke-47 dan Q.S. Hud ke-52. (Q.S. al-Araf/7 : 85, Q.S. al-Shu'ara'/26 : 181183, Hud/11 : 84-88). Selain menyeru mereka untuk menyembah kepada Allah, Nabi Syuaib memperingatkan mereka untuk meninggalkan beberapa kebiasaan jahat mereka yakni tindak kecurangan berkaitan dengan perdagangan, yaitu : a) mengurangi ukuran dan timbangan, b) memperkosa hak-hak rakyat, c) membuat kerusakan dan keonaran.

\section{b. Harta dan Fungsinya}

Setelah meluruskan pandangan dasar manusia tentang dunia dan harta kemudian membimbing untuk mengimani kehidupan akhirat yang kekal, maka ditunjukkanlah ajaran-ajaran yang benar bagaimana memandang dan memperlakukan dunia dan harta. Di antaranya adalah ajaran tentang fungsi sosial dari harta yang menyatakan bahwa harta tidaklah hanya untuk dipakai dan dinikmati sendiri dan keluarganya, karena banyak orang lain yang tidak mampu memenuhi kebutuhan hidupnya. Mereka yang memiliki harta harus mempunyai peduli kepada mereka yang tidak mampu : anak yatim, fakir-miskin, kerabat yang kekurangan serta para budak. Ayat-ayat Makkiyah yang bicara seperti ini adalah Q.S. al Ma'un/107 : 1-7, Q.S. alBalad/90 : 11-16, Q.S. al-Dhariyat/51 : 19. Q.S. al-Ma'un/107 yang turun ke-17, al-Quran mengecam keras orang yang tak mau memberikan bantuan itu, dengan disebut mendustakan agama (yukadzdzibu biddin). Dalam surah al-Balad yang turun ke-35, dinyatakan bahwa upaya seperti itu tidaklah mudah sehingga disebut dengan jalan terjal dan mendaki (al-'aqabah).

\section{c. Larangan Berlebihan dan Boros}

Kenikmatan dunia dan harta tidaklah terlarang bagi orang mukmin, karena itu merupakan anugerah Allah yang diberikan kepada hamba-Nya, terutama yang beriman. Namun dalam memanfaatkan dan membelanjakan harta yang dimiliki sebagai anugerah dan kemurahan Allah, al-Quran memperingatkan agar manusia menggunakannya dengan sederhana sesuai dengan kebutuhan dan kemampuannya, tidak berlebih lebihan (israf) dan sia-sia (tabdzir). Dalam Q.S. al-Araf/ : 3133, Q.S. alFurqan/25 : 67 dan Q.S. al-Isra'/17 : 26-30 secara garis besar Allah mengajarkan agar manusia dalam membelanjakan harta tidak berlebihan (israf), tidak siasia (tabdzir) dan juga tidak kikir (taqtir). Dalam Q.S. al-Araf/7: 31, surah yang turun ke-39, mulamula diajarkan untuk berpakaian yang bagus setiap hendak melakukan shalat dan melakukan ibadah. Sebagaimana ditegaskan pada ayat berikutnya (ayat 32) bahwa

19 Penduduk Madyan disebut juga Ashhab al-Aikah (Penghuni Hutan) adalah kaum Nabi Syu'aib. Dinisbahkan kepada Madyan, mula-mula nama salah seorang anak Nabi Ibrahim yang kemudian dikenal sebagai nama suku dan tempat dari Teluk Aqabah sampai ke Tursina, Diungkap dalam surah Hud, mereka sebelumnya adalah orange orang yang hidup makmur dan cukup, meski tanpa melakukan kecurangan dalam perdagangan. Namun, ketamakan dan kerakusan mereka terhadap harta membuat mereka melakukan tindak curang dan jahat serta bersikap sombong tak mau menerima nasihat-nasihat yang diberikan oleh Syu'aib yang dianggap sebagai orang hina karena tidak kaya seperti mereka hingga tak pintas mereka ikuti.

207| al-@urhan: Kajian Ilmu dan Pengembangan Budaya Al-Qur'an, Vol. 20, No. 2, Desember 2020: $198-215$. 


\section{Suhada}

Allah tidak mengharamkan hiasan dan kenikmatan dunia kepada umat Islam, karena hal itu akan menunjukkan nikmat dan anugerah Allah untuk diketahui, dicari dan disyukuri. Bahkan dalam suatu hadits dinyatakan: "Dari 'Amr ibn Syu'aib dari ayahnya dari kakeknya bahwa Rasulullah Saw bersabda Sesungguhnya Allah senang bila bekas nikmat yang diberikan itu nampak pada hamba-Nya". (HR at-Tirmidhi)

Larangan berlebihan (israf) ditegaskan kembali dalam Q.S. al-Furqan/25, surah yang turun ke-42 dengan ungkapan walam yaqturu (berasal dari qatr berarti kikir) serta dalam.al-Isra'/17, surah yang turun ke-50 dengan wala tubadzdzir tabdzira. Perilaku berlebihan, boros dan sia-sia selain merugikan dan membuat seseorang menyesal dan terhina juga dikecam sebagai perbuatan setan yang ingkar kepada Allah. Sedang cara yang diperintahkan adalah cara yang sedang (cukup) dan hemat (iqtishad). ${ }^{20}$

\section{d. Kemurahan Allah untuk Manusia}

Setelah menekankan dasar dan moral-etika perekonomian dengan bentuk ungkapan negatif yang mengecam, pengingkaran atau larangan sebagai ungkapan pembongkaran (dekonstruktif), selanjutnya al-Quran menggugah mereka agar berpikir secara positif (rekonstruktif) berkaitan dengan aspek-aspek perekonomian, seperti pengenalan tentang sumber daya clam berupa tumbuh-tumbuhan, peternakan, perikanan, makanan, kendaraan dan lain-lain. ${ }^{21}$ Ayat-ayat tersebut dapat ditemui dalam surah-surah Makkiyah tahap awal, pertengahan dan akhir, antara lain Q.S. 'Abasa yang turun ke-24, Q.S. al-Mursalat ke-33, Q.S. Qaf ke-34, Q.S. al-Araf ke-39, Q.S. Yasin ke-41, Q.S. al-Waqi'ah ke-46, Q.S. al-Hijr ke-54, Q.S. az-Zumar ke59 dan Q.S. al-Mulk ke-77 sebagai berikut:

\section{Bumi Sebagai Tempat dan Sumber Penghidupan}

Segala sesuatu di muka bumi ini, dengan kekuasaan Allah, diatur untuk memenuhi kebutuhan dan memberi kesenangan manusia sebagai makanan baginya dan juga untuk binatang ternaknya. Untuk mewujudkan manfaat itu Allah menurunkan air yang datang dari awan (langit) dalam jumlah yang besar. Dengan adanya air, maka bumi diolah, dicangkul dan dibajak. Dengan ditaburkan benih ke dalam tanah maka tumbuhlah tanam-tanaman dengan berbagai macamnya, baik padipadian, sayur-sayuran, buah-buahan yang tahan lama seperti zaitun dan korma, maupun yang tidak.

Perpaduan dan putaran antara bumi, disiram oleh air hujan air diserap oleh bumi dan mengalir sungai yang bermuara ke laut, kemudian terjadilah awan yang dibawa angin terbang di langit kemudian menurunkan hujan yang tersebar

${ }^{20}$ Al-Maraghi menjelaskan: (1) Biologis, seperti haus dan lapar atau kenyang. Hendaknya berhenti makan dan minum bila sudah kenyang. (2) Ekonomis, belanja yang sesuai dengan pendapatan dengan tidak menghabiskan semuanya. (3) Agamis, tidak makan dan minum yang dilarang agama seperti bangkai, darah, daging babi, atau minum khamr, atau pakaian sutera yang murni bagi lelaki. Cara yang sederhana, tidak berlebihan dan tidak kikir, telah dicontohkan oleh Nabi Muhammad dan para sahabatnya, sebagaimana dikatakan oleh Yazid ibn Abi Hubaib, bahwa mereka makan-minum bukan untuk mencari kelezatan dan keenakan tetapi untuk menghilangkan lapar dan haus; berpakaian bukan untuk kebanggaan dan keindahan tetapi untuk menutup aurat, melindungi badan dari panas dan dingin.

${ }^{21}$ Aziz, Abd. "Pendidikan Etika Sosial Berbasis Argumentasi Quranik." Andragogi: Jurnal Pendidikan Islam dan Manajemen Pendidikan Islam 1.3 (2019): 466-489.

at-8urhan: Kajian Ilmu dan Pengembangan Budaya Al-Qur'an, Vol. 20, No. 2, Desember 2020: 198-215| 208 


\section{Suhada}

membasahi seluruh permukaan bumi merupakan sunnatullah yang teratur melengkapi kebutuhan hidup manusia. Bahkan Allah menyediakan segala sesuatu di muka bumi itu menurut perimbangan dan ukuran yang serasi , tertib, harmonis, indah dan agung (Q.S. al-Hijr/15 :19-21). Dunia mineral menopang dunia nabati, dan pada gilirannya keduanya menopang makhluk hewani dengan suatu lingkaran ketergantungan antar semuanya. Semua itu adalah rezeki Allah yang disediakan sebagai penghidupan (ma'ayish) bagi seluruh makhluk, tidak terbatas hanya untuk kamu orang mukmin, tetapi mencakup manusia yang mukmin atau kafir, juga binatang dan semua makhluk lain, meski mereka tidak menyadari. Termasuk keluarga, kerabat dan orang-orang yang menjadi tanggunganmu hakikatnya Allahlah yang memberi rezeki mereka, bukan kamu (Q.S. al-Hijr/15 : 20).

Bumi juga diciptakan Allah dapat dikelola (Q.S. al-Mulk/67 : 15) oleh manusia. Abdullah Yusuf Ali mengatakan bahwa manusia dapat mengelolanya menjadi jalan, menghubungkannya dengan jembatan, menerobos dengan terowongan, melintasi gunung, mengarungi sungai dan lautan, melintasi dengan pesawat terbang. Sebagai perantara untuk mampu mengelola sernua itu Allah memberikan kecerdasan otak kepada manusia. ${ }^{22}$

\section{Bumi Sebagai Tempat Kediaman}

Dalam Q.S. al-A'raf/7 : 24-26 yang turun ke-39 Allah menyatakan bahwa manusia ditetapkan menempati bumi, baik ketika masih hidup maupun setelah mati (dikubur di dalam tanah). Secara garis besar Q.S. Taha/20 : 117-119 yang turun ke-45 mengisyaratkan jenis-jenis kebutuhan pokok manusia sebagaimana akan dinikmati saat ada di surga, yaitu makan minum (pangan), pakaian (sandang) dan rumah tempat tinggal (papan).

Selanjutnya, secara lebih detail Q.S. al-Nahl/16 : 8o-82 yang turun ke-7o menyatakan bahwa manusia dengan potensi sosial, intelektual dan ruhaninya dapat membuat rumah sebagai tempat tinggal yang tenang (sakan) yang lazim bagi manusia yang menetap. Sedang manusia yang biasa berpindah-pindah atau dalam perjalanan dapat membuat tempat tinggal sementara berupa kemah dari kulit yang mudan dibawa ke mana saja saat berjalan dan dipasang saat berhenti. Dari bulu domba yang halos manusia dapat membuat peralatan rumah-tangga seperti untuk hamparan dan kasur. Dalam ayat-ayat tersebut juga disebutkan di antara nikmat Allah bahwa manusia dapat membuat pakaian yang berfungsi untuk menutup 'aurat serta melindungi diri dari panas dan dingin. Atau dengan baju besi manusia bisa melindungi diri dari bahaya dan luka-luka saat berperang menghadapi musuh.

\section{Binatang Ternak Sebagai Kendaraan dan Makanan}

Binatang ternak (al-An'am) yang diciptakan Allah dengan memiliki banyak manfaat bagi manusia. Bila dalam Q.S. Yasin/36 : 71-73 yang turun ke-41 dan surah alAn'am/6 : 142.144 yang turun ke-55 ditunjukkan manfaat binatang ternak secara global untuk kendaraan, dimakan dagingnya dan juga diminum susunya, maka pada surah anNahı/16 : 66-69 yang turun ke-70 dan Q.S. al-Mukminun/ $23:$ 21-22 yang turun ke74 diuraikan lebih rinci, antara lain :

${ }^{22}$ Abdullah Yusuf Ali, Qur'an Terjemahan dan Tafsirnya, 1473, 1562, 1567.

209| at@8urhan: Kajian Ilmu dan Pengembangan Budaya Al-Qur'an, Vol. 20, No. 2, Desember 2020: 198-215. 


\section{Suhada}

a) Sebagai kendaraan (alat transportasi), yang membantu manusia untuk menempuh perjalanan jauh dengan membawa muatan yang berat. Pada saat turunnya AlQuran di Arabia alat transportasi yang efektif adalah unta, jenis binatang yang mempunyai ketahanan fisik luar biasa, juga kuda dan keledai (bighal dan hamir) yang semuanya mampu mengarungi lautan padang pasir dan jarak yang jauh membantu manusia membawa beban manusia maupun barang yang berat yang tak mungkin dibawa oleh manusia sendiri. Dalam menafsirkan akhir ayat 8 anNahl di atas (wa yakhluq ma la ta'lamun), al-Maraghi mengatakan bahwa Allah juga akan menciptakan alat-alat transportasi yang belum diketahui saat itu. selain binatang yang sudah disebut, antara lain kendaraan yang ditemukan di zaman modern seperti mobil, kereta api, terbang, kapal, kapal selam dan lain-lain. ${ }^{23}$

b) Sebagai makanan, yakni daging binatang ternak menjadi makanan bagi manusia karena mengandung kalori yang banyak. Bagi bangsa Arab yang hidup di padang pasir daging binatang ternak seperti unta, kambing, sapi sangat menunjang kebutuhan gizi dan kesehatan mereka sehingga mereka mempunyai ketahanan tubuh yang prima.

c) Di antara binatang ternak itu, seperti sapi dan kambing, mempunyai kandungan air susu yang segar dan banyak serta sangat tinggi kandungan gizinya. Air susu binatang ternak itu dapat menjadi minuman manusia juga menjadi makanan yang lezat dan bergizi. Selain binatang ternak, Allah juga menciptakan lebah yang dapat mengeluarkan madu yang beragam warnanya, suatu jenis makanan yang lezat dan mengandung unsur-unsur glukosa, lyophilize yang berguna untuk menjadi obat bagi berbagai macam penyakit.

\section{Laut sebagai media transportasi dan sumber perikanan dan mutiara}

Salah satu ungkapan yang indah tentang laut adalah ayat 14-15 an-Nahl. ${ }^{24}$ Dalam surah Makiah yang turun tahap akhir itu (an-Nahl-70) secara rinci diungkap manfaat laut bagi manusia, antara lain; menjadi jalan untuk kapal-kapal sebagai alat transportasi yang menghubungkan antara satu pulau dengan pulau yang lain, bahkan antara satu benua dengan benua yang lain. Jalan laut merupakan jalan yang efektif sejak masa awal peradaban manusia; menjadi sumber perekonomian dengan adanya ikan dan berbagai jenis batu karang mutiara serta biota laut lainnya.

\section{Petunjuk Berusaha dan Kerja}

Selain hal-hal di atas, dalam surah-surah Makiah dapat ditemui beberapa prinsip atau petunjuk yang penting tentang perekonomian, yaitu:

a) Perdagangan antar negara (Quraisy/ 106: 1-4)

b) Pemanfaatan waktu

1. Mengisi waktu untuk bekerja (al-Sharh/94:7-8)

${ }^{23}$ Ahmad Mushthafa al-Maraghi, Jilid V Juz XIV, 57.

24 Dan Dia-lah, Allah yang menundukkan lautan (untukmu) agar kamu dapat memakan daripadanya daging yang segar (ikan), dan kamu mengeiuarkan dari lautan itu perhiasan yang kamu pakai, dan kamu melihat bahtera berlayar padanya, dan supaya kamu mencari (keuntungan) dari karunia-Nya, dan supaya kamu bersyukur. Dan Dia menancapkan gunung-gunung di bumi supaya bumi itu tidak goncang bersama kamu. (dan Dia menciptakan) sungai-sungai dan jalan-jalan agar kamu mendapat petunjuk, dan (Dia ciptakan) tanda-tanda (penunjuk jalan). (QS. An-Nah1/16:14.15).

al-\$urhan: Kajian Ilmu dan Pengembangan Budaya Al-Qur'an, Vol. 20, No. 2, Desember 2020: 198-215| 210 


\section{Suhada}

2. Allah memberikan waktu malam yang gelap untuk tidur dan istirahat sementara membuat siang untuk bekerja (al-Furqan:47)

c) Membangun prestasi (al-Najm/53:39-40)

d) Tenaga-kerja dan upah (al-Qashash/28:23-28). ${ }^{25}$

e ) Kerja sama dan solidaritas sosial (al-Zukhruf/43:32)

Dalam surah al-Zukhruf yang turun ke-63 terdapat ajaran penting tentang sistem kerja-sama dalam masyarakat, yaitu pernyataan tentang adanya perbedaan tingkatan manusia dalam kemampuan ekonomi (ma'isyah) sesuai dengan kehendak Allah (sunnatullah) karena Dialah yang membagi-bagi perekonomian itu. Adanya perbedaan itu dimaksudkan agar terjadi suatu kerja sama, saling pengertian dan saling membantu bukan persaingan untuk permusuhan yang menonjolkan kepentingan masing-masing kelompok.

f) Pengembangan Teknologi

Dalam ayat Makiah ditemukan ayat-ayat yang mengungkap tentang pengembangan teknologi, antara lain Teknologi Pembuatan Kapal (Q.S. Hud/11 : 3738) dan Pembuatan Baju-besi (Q.S. al-Anbiya'/21 : 8o)

g) Anjuran memberi kepada kerabat, orang miskin, ibn sabil. Juga informasi awal tentang riba dan kebaikan zakat, meski belum dengan tegas dan rinci (Q.S. al-Rum/30 $: 38-39){ }^{26}$

\section{Mengatasi Krisis, Belajar dari Nabi Yusuf}

Kisah Nabi Yusuf ${ }^{27}$ (surah Yusuf/12, turun ke-53) dengan menarik mengungkap aspek politik, ekonomi, hukum, detektif, intelijen, kriminalitas serta romantika cinta.

${ }^{25}$ Dalam surah al-Qashash yang turun ke-49 dikisahkan, saat Musa pergi dari Mesir dan sampai di Madyan bertemu dengan dua orang putri yang menggembalakan kambing engantri karena tak bisa meminumkan kambing yang sedang menunggu mengantri karena tak bisa meminum digembalakan. Melihat keduanya tak berani mengantri, Musa membantu mereka meminumkan kambing tersebut. Mereka pun melaporkan kepada ayah mereka yang sudah tua (syaikh kabir), dan Musa dipanggil untuk diberi upah atas bantuannya dan kemudian diminta untuk bekerja kepadanya karena dia dianggap orang yang kuat fisiknya dan jujur, dapat dipercaya (al-amin). Selanjutnya terjadilah transaksi penyewaan tenaga (ijarah) antara Syaikh sebagai penyewa (musta'jir) dan Musa sebagai yang disewa (mustajar). Musa diminta bekerja selama delapan tahun atau kalau mau sampai sepuluh tahun dengan upah (bayaran, ujrah) dan dinikahkan dengan salah seorang putrinya. Artinya upah pekerjaan selama delapan tahun itu sebagai mahar (maskawin). Sementara itu, dalam menafsirkan Syaikh kabir ada yang menyebutnya Nabi Syu'aib, tetapi Ibn Katsir dan al-Maraghi menolaknya karena antara Syu'aib dan Musa terpaut waktu sekitar 400 tahun. Lihat Abul-Fida Isma'il Ibn Katsir, Tafsir Ibn Katsir, Juz III, 386 dan al-Maraghi, Jilid VII, Juz 20, 50.

${ }^{26}$ Riba di sini berbeda dengan yang ada di surah al-Baqarah/2 dan Alu 'Imran/ 3 (Madaniyah), adalah pemberian kepada seseorang dengan maksud memperoleh balasan yang lebih banyak. Pemberian semacam ini tak akan memperoleh pahala di sisi Allah. Riba semacam ini boleh, tidak dilarang, menurut para muafassir seperti Ibn 'Abbas, Mujahid, Dhahhak, Qatadah, Ikrimah dan Ibn Ka'b. Menurut Ibn 'Abbas riba ada dua, riba dalam jual beli dan hutang piutang hukumnya haram, dan riba dalam pemberian sebagaimana dimaksud ayat ini. Lihat Abū al-Fidā Isma'īl Ibn Katsir, Tafsīr Ibn Kathīr, Jilid II, 531, al-Maraghi, jilid VII Juz XXI, 52.53.

${ }^{27}$ Yusuf adalah anak Ya'kub yang juga disebut Israil, cucu Ibrahim dari anaknya Ishak. Mereka berasal dari daerah Palestina sebelah selatan, suatu daerah miskin yang sering mengalami kelaparan. Mereka lebih tertarik mencari penghidupan ke Mesir, delta sungai Nil yang subur dan makmur. Nabi Yusuf hidup pada masa Dinasti Hykos 2000 - 160o SM. Dan oleh salah seorang raja (Firaun) dari Dinasti 211 at-\$urhan: Kajian Ilmu dan Pengembangan Budaya Al-Qur'an, Vol. 20, No. 2, Desember 2020: 198-215. 


\section{Suhada}

Surat itu juga mengungkap perekonomian dalam perspektif makro dan politik ekonomi. Menghadapi krisis yang dialami di negerinya, keluarga Ya'kub (ayah Yusuf) harus melakukan urbanisasi (emigrasi) ke Mesir untuk mengimpor bahan pokok. Ketika di Mesir sendiri perekonomian juga tidak stabil, Yusuf yang melalui perjalanan dramatis menjadi anak angkat perdana menteri, akhirnya menunjukkan keahliannya sebagai seorang ekonom. Ia mampu merencanakan dan mengelola perekonomian negeri itu sehingga selamat dari krisis yang ditakutkan.

Salah satu episode mengungkap ketika Yusuf yang berada di penjara memperoleh perhatian dari Raja, yang menurut ahli sejarah bernama al-Walid ibn Rayyan. Sang Raja bermimpi melihat tujuh ekor sapi betina gemuk yang keluar dari sungai ditelan oleh tujuh ekor sapi yang kurus, juga tujuh bulir gandum yang hijau ditelan oleh tujuh bulir gandum yang kering. Ketika ahli tabir mimpi menganggap sebagai mimpi kosong, Yusuf yang ditanya tabir mimpi Raja menafsirkan mimpi Raja tersebut dalam program perekonomian negara dalam rangka mengatasi krisis ekonomi yang akan terjadi. Tafsir mimpi itu antara lain:

a. Selama tujuh tahun berturut-turut basil pertanian akan melimpah ruah. Program yang harus dilakukan saat itu, di camping untuk memenuhi kebutuhan logistik, perlu dilakukan penyimpanan sebagian basil panen untuk menghadapi masa sulit berikutnya. Ini merupakan makna dari mimpi tentang tujuh ekor sapi gemuk dan tujuh bulir gandum yang hijau.

b. Akan datang setelah itu masa kering dan paceklik selama tujuh tahun. Pada saat itu rakyat akan memenuhi kebutuhan logistiknya dari simpanan yang dilakukan sebelumnya. Ini adalah makna dari mimpi tentang tujuh ekor sapi kurus dan tujuh bulir gandum yang kering.

c. Setelah masa kering dan paceklik itu akan datang masa pemulihan ekonomi (economic recovery) dan kemakmuran dengan datangnya kemudahan dan kemurahan Allah yang membuat berbagai usaha pertanian dan perekonomian memperoleh hasil yang memuaskan.

Akhirnya, begitu Raja melihat Yusuf yang masih muda (30 tahun) dengan segala integritas moral dan keahliannya, maka dia mengangkatnya sebagai perdana menteri. Yusuf pun menyediakan diri untuk mengurus perekonomian yaitu mengelola perbendaharaan negara serta penyimpanan logistik. Sebagai seorang ahli ekonomi, Yusuf merancang perekonomian negara secara makro untuk menghadapi krisis dan mewujudkan stabilitas ekonomi negara serta kemakmuran. Dia menggalakkan penanaman pada musim subur, melakukan penyimpanan hasil panen selama musim subur, kemudian mengeluarkan dan menjualnya pada masa kering dan paceklik untuk akhirnya akan mencapai situasi ekonomi stabil sehingga terwujud kemakmuran.

Kajian tentang ekonomi menurut al-Quran sangat relevansi dengan situasi sekarang di mana ekonomi Islam menjadi suatu wacana bukan hanya bermotif keagamaan tetapi juga keilmuan dan tuntutan realitas sosial. Sejak tahun 70-an telah muncul gagasan aksi dan usaha konseptualisasi ekonomi Islam, terutama dimulai dari sektor moneter dan perbankan. Gagasan yang kemudian melahirkan berdirinya perbankan syari'ah itu pada dasarnya secara teoretis makro menghendaki perumusan sistem ekonomi Islam sebagai alternatif terhadap sistem perekonomian kapitalis yang

Hykos ini Pula (menurut ahli sejarah bernama al-Walid ibn Rayyan) dia akhirnya diangkat sebagai perdana menteri. Lihat Abdullah Yusuf Ali, Qur'an Terjemahan dan Tafsirnya, 405, 571.

al-\$urhan: Kajian Ilmu dan Pengembangan Budaya Al-Qur'an, Vol. 20, No. 2, Desember 2020: 198-215| 212 


\section{Suhada}

didasari filsafat materialisme. Melihat latar historis serta konteks sosio-kultural dan tema pokok ayat-ayat Makiah seperti diungkap di atas, pembentukan masyarakat ternyata diawali dengan membongkar pandangan (world view) masyarakat un berkaitan dengan harta dan keduniaan. Pandangan mereka direkonstruksi dengan memberikan dasar-dasar teologis melalui pembebasan pikiran dan pengembalian kepada hakikat kehidupan, seperti asal-muasal dan muara akhir kehidupan (akherat) yang semuanya bersandar kepada Tuhan. Dasar teologis ini berlawanan secara diametral dengan filsafat materialisme yang memandang kebahagiaan manusia hanya ditentukan aspek material semata yang menjadi dasar dari system ekonomi sekarang (konvensional). Perbedaan paradigmatik itu melahirkan perbedaan-perbedaan prinsip, sistem dan teknik operasional perekonomian Islam dengan system perekonomian konvensional, yang kini sedang menjadi wacana di kalangan ahli ekonomi, dalam rangka memperoleh alternatif yang lebih sesuai dengan nilai-nilai kemanusiaan.

\section{Kesimpulan}

Demikianlah secara garis besar petunjuk tentang ekonomi yang terdapat dalam surah dan ayat Makiah dapat disimpulkan bahwa pertama; pengajaran tentang pengaruh harta keduniaan yang bisa menurunkan jiwa dan pikiran manusia, seperti durhaka, sombong, menindas (zalim), menipu, pemikiran bebas, tidak menghormati orang lain dan hilangnya moral. Kedua; ada sifat-sifat manusia yang berlebihan dalam mencintai harta dan takut miskin sehingga mengabaikan Tuhan dan mengabaikan orang lain. Karena itu, pengajaran tentang fungsi harta yang bisa dipakai untuk meraih kebaikan, baik sebagai ibadah vertikal kepada Allah maupun ibadah horizontal dengan sesama manusia, seperti sedekah, nafkah, menyantuni anak yatim, orang miskin dan ibn sabil. Teladan dari orang dan umat terdahulu yang binasa karena godaan harta dengan pandangan yang salah terhadap harta atau perilaku buruk dalam berdagang yang merugikan orang lain, seperti kisah pemilik kebun, kaum Madyan (ashab al-aykah). Wawasan tentang penataan ekonomi makro dalam mengatasi krisis dan membangun kesejahteraan seperti tampak pada kisah Nabi Yusuf. Informasi awal tentang buruknya riba serta kebaikan zakat. 


\section{Daftar Pustaka}

'Alī 'Abd al-Rasūl, al-Mabādi al-Iqtiṣādiyah fì al-Islām, Kuwait: Dār al-Fikr 'Arabī, 1980, Cet II.

Abdullah Yusuf Ali, Qur'an Terjemah dan Tafsirnya, Jakarta: Pustaka Firdaus, 1995, Cet I, 1660.

Abdullah Yusuf Ali, Qur'an Terjemahan dan Tafsirnya, Jakarta: Pustaka Firdaus 1993, Juz I-XV, Cet. I.

Abul-Fida Isma'il Ibn Katsir, Tafsir Ibn Katsir, Juz IV.

Abul-Fida Isma'il Ibn Katsir, Tafsir Ibn Katsir, Riyadh : Maktabah Riyadh alHaditsah, t.th, Juz IV.

Ahmad Mushthafa al-Maraghi, Jilid V Juz XIV.

Attamimi, Munif Mahadi, and Muhammad Hariyadi. "Al-Qur' an Answering the

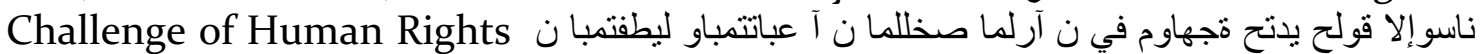

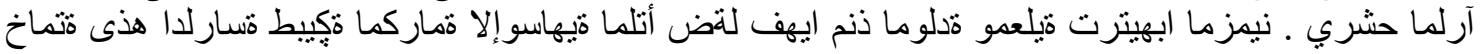

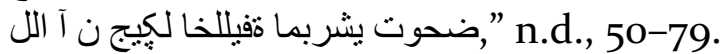

Asghar Ali Engineer, Asal Usul dan Perkembangan Islam, Analisis Pertumbuhan SosioEkonomi, Yogyakarta : Insist dan Pustaka Pelajar, 1999, Cet I.

Aziz, Abd. "Al-Qur'an Dan Sastra: Antara Etika, Estetika, Dan Profetika." Al-Burhan| Jurnal Kajian Ilmu dan Pengembangan Budaya Al-Qur'an 20.1 (2020): 147-163.

Aziz, Abd, and M. Imam Sofyan Yahya. "Kritik Intrinsikalitas dan Ekstrinsikalitas Sastra Modern dalam Kajian Sastra Arab Modern." Mumtaz: Jurnal Studi AlQuran dan Keislaman 3.1 (2019): 23-36.

Aziz, Abd. "Pendidikan Etika Sosial Berbasis Argumentasi Quranik." Andragogi: Jurnal Pendidikan Islam dan Manajemen Pendidikan Islam 1.3 (2019): 466-489.

Febriani, Nur Arfiyah, Badru Tamam, M Darwis Hude, Hamdani Anwar, and Muhammad Suaib Tahir. "GLOBAL CITIZENSHIP EDUCATION IN THE PERSPECTIVE OF QUR ’ AN AND.” Psychology and Education Journal 57, no. 57 (2020): 5020-29.

Hariyadi, Muhammad. "METODOLOGI TAFSIR AL-QUR'AN KONTEMPORER SALAM PENDEKATAN ILMU KOMUNIKASI MODERN.” Jurnal Statement 11, no. 1 (2021): 30-40.

HAR Gibb, Mohammadanism, t.tp: London, 1919.

Hassan Ibrahim Hassan, Sejarah Kebudayaan Islam, Jakarta: Kalam Mulia, 2002.

Ira M. Lapidus, Sejarah Sosial Umat Islam I E II, Jakarta: Raja Grafindo Persada, 1999, Cet. I.

Kadim as-Sadr, "Uang dan Kebijakan Moneter pada Periode Awal Islam" dalam Adiwarman Karim, ed, Sejarah Pemikiran Ekonomi Islam, Jakarta: IIIT, 2002, Cet II.

Muh. Zuhri, Riba dalam al-Qur'an, Jakarta: Raja Grafindo Persada, Cet. II.

Saihu, Made, and Abdul Aziz. "Implementasi Metode Pendidikan Pluralisme Dalam Mata Pelajaran Pendidikan Agama Islam." Belajea: Jurnal Pendidikan Islam 5.1 (2020): 131-150.

Saihu, Abd Aziz, Baeti Rohman, Suhada, "Religious Argumentation of Hate Speech (Critical Race and Racism in Hate Speech Phenomena in Indonesia)." Journal International Journal of Innovation, Creativity and Change 13.10 (2020): 1176-1194. Saihu, Abd. Aziz. "Implementasi Metode Pendidikan Pluralisme Dalam Mata Pelajaran al-৫urhan: Kajian Ilmu dan Pengembangan Budaya Al-Qur'an, Vol. 20, No. 2, Desember 2020: 198-215 | 214 


\section{Suhada}

Pendidikan Agama Islam Saihu." Belajea: Jurnal Pendidikan Islam 5, no. 1 (2020): 131-50. https://doi.org/10.29240/belajea.v5.

Wahbah al-Zuhaylī, al-Tafsīr al-Munīr fi al-Sharī'ah wa al-Manhaj, Beirut: Dār al-Fikr al-Mu'așir, 1998, Juz 30.

215 |at-ஷurhan: Kajian Ilmu dan Pengembangan Budaya Al-Qur'an, Vol. 20, No. 2, Desember 2020: 198-215. 